\title{
A review of nest and egg descriptions for the genus Myrmeciza, with the first description of nests and eggs of the dull-mantled antbird (M. laemosticta)
}

\author{
Harold F. Greeney • César Sánchez • \\ Julio E. Sánchez · Ernesto Carman
}

Received: 23 August 2012/Revised: 9 April 2013/Accepted: 24 May 2013/Published online: 14 June 2013

(C) The Author(s) 2013. This article is published with open access at Springerlink.com

\begin{abstract}
We review published information on the nests and eggs of members of the polyphyletic genus of antbirds, Myrmeciza, and present the first descriptions of nests and eggs of the Dull-mantled Antbird M. laemosticta, based on three nests found in Costa Rica. We identify three distinct nest architectures within the group: bulky, bottom-supported, open cups of coarse vegetative matter; rim-suspended open cups of neatly woven fine materials; and bulky domed nests made of coarse vegetative materials. The majority of described nests (eight) belong to the first category, but the nests of $M$. atrothorax and M. hemimelaena have unique architectural characters which may prove to be phylogenetically informative. The nests of M. laemosticta are rim-suspended, open cups made of fibers, similar to those of $M$. palliata and M. hyperythra. As molecular data suggest that $M$. hyperythra is more closely related to Schistocichla than to M. laemosticta and M. palliata, these likely represent independent derivations of the rim-suspended architecture. M. melanoceps, $M$. goeldii, and $M$. fortis belong to the third architectural group, united by the construction of domed nests similar to hypothesized relatives. We conclude that nest architecture
\end{abstract}

Communicated by J. Fjeldså.

H. F. Greeney $(\bowtie)$

Yanayacu Biological Station and Center for Creative Studies,

c/o Foch 721 y Amazonas, Quito, Ecuador

e-mail: revmmoss@yahoo.com

C. Sánchez

Department of Biological Sciences and Museum of Natural

Science, Louisiana State University, 119 Foster Hall,

Baton Rouge, LA 70803, USA

J. E. Sánchez · E. Carman

Asociación de Ornitólogos Unidos de Costa Rica,

11695-1000 San José, Costa Rica is phylogenetically informative within this group and supports molecular-based hypotheses. However, more nest descriptions are needed for all species, in particular M. longipes, M. berlepschi, M. pelzelni, and M. disjuncta; and future descriptions should include architectural details such as the manner in which nests are supported by or attached to their substrate.

Keywords Dull-mantled Antbird · Egg · Myrmeciza . Nest $\cdot$ Phylogenetically informative

\section{Zusammenfassung}

Eine Übersicht über Nest- und Ei-Beschreibungen der Gattung Myrmeciza, mit einer Erstbeschreibung von Nest und Eiern des Grauscheitel-Ameisenvogels (M. laemosticta)

Wir stellen veröffentlichte Informationen über Nester und Eier von Mitgliedern des polyphyletischen Gattung der Ameisenvögel, Myrmeciza, zusammen und liefern eine erste Beschreibung von Nestern und Eiern des GrauscheitelAmeisenvogels M. laemosticta anhand von drei Nestern aus Costa Rica. Wir stellen drei verschiedene Nest-Typen innerhalb der Gruppe fest: massige, aufsitzende, offene Becher aus grobem Pflanzenmaterial; am Rand getragene offene Becher aus ordentlich verwobenem feinen Material; und massige gewölbte Nester aus grobem Pflanzenmaterial. Der Großteil der beschriebenen Nester gehört zur ersten Kategorie, aber die Nester von M. atrothorax und M. hemimelaena weisen einzigartige Baueigenschaften auf, die möglicherweise phylogenetische Rückschlüsse erlauben. Die Nester von M. laemosticta sind am Rand getragene, offene Becher aus Fasern, ähnlich denen von M. palliata und M. hyperythra. Da molekulare Daten darauf hindeuten, dass 
M. hyperythra näher mit Arten der Gattung Schistocichla als mit M. laemosticta und M. palliata verwandt ist, stellt diese Bauweise wahrscheinlich eine unabhängige Ableitung von der Architektur anderer am Rand getragener Nest-Typen dar. $M$. melanoceps, $M$. goeldii und $M$. fortis gehören zur dritten Gruppe, die sich durch die Konstruktion gewölbter Nester auszeichnet, ähnlich der der angenommenen Verwandten. Wir schließen daraus, dass Nestarchitektur in dieser Gruppe phylogenetische Informationen bietet, die molekular basierte Hypothesen unterstützt. Allerdings werden mehr Beschreibungen von Nestern für alle Arten benötigt, insbesondere für M. longipes, M. berlepschi, M. pelzelni und M. disjuncta. Zukünftige Beschreibungen sollten Details zur Bauweise enthalten, wie die Art und Weise, in der das Nest auf dem Substrat aufliegt oder befestigt ist.

Keywords Dull-mantled Antbird - Egg - Myrmeciza . Nest · Phylogenetically informative

\section{Introduction}

As currently defined, the antbird genus Myrmeciza includes 22 species of antbirds (Thamnophilidae; (Chaves et al. 2010; Donegan 2012; Remsen et al. 2013). Recent molecular studies (Brumfield et al. 2007; Irestedt et al. 2004; Moyle et al. 2009), along with a growing number of nest descriptions, however, have revealed the now widely accepted view that Myrmeciza is polyphyletic (Bravo 2012; Remsen et al. 2013; Ridgely and Tudor 1994; Zimmer and Isler 2003). Records of nest architecture and egg coloration within Myrmeciza are, in some cases, unclear or disputed and are scattered throughout the literature, making it difficult to synthesized current knowledge.

Here we review published information on Myrmeciza nests and eggs, and we interpret vague descriptions in the light of our own experience with Neotropical bird nests. We also provide the first description of the nests and eggs of M. laemosticta from Costa Rica. Nest architecture and other life-history traits are thought to be phylogenetically informative for many groups of birds (Greeney and Port 2010; Miller and Greeney 2008; Sheldon and Winkler 1999; Zyskowski and Prum 1999), including thamnophilids (Restrepo and Londoño 2011). Using recent molecular phylogenies of Myrmeciza and related species (Bravo 2012), we examine to what extent nest architecture reflects phylogeny in this polyphyletic group.

\section{Methods}

We exhaustively reviewed the literature concerning the reproductive habits of Myrmeciza antbirds. For each species, we provide a chronology of published information and, if applicable, a brief discussion or interpretation. Data are presented in the taxonomic order used by Remsen et al. (2013), with the exception of M. laemosticta, for which we present our previously unpublished data at the end. We found no published information on the nest or eggs of M. castanea, M. disjuncta, M. griseiceps, M. berlepschi, M. pelzelni, M. zeledoni, M. immaculata, or M. laemosticta.

\section{Results}

White-bellied antbird (M. longipes)

Belcher and Smooker (1936) described nests from Trinidad as "shallow saucer(s) of brown pliable twigs and rootlets, with exteriorly a few light-coloured straw-like stalks, and an inner lining of black material like horsehair" which are "placed upon or set in among (their) supports rather than slung." They stated that nests are generally found ca. $2 \mathrm{~m}$ above the ground and that eggs are "dull white in ground-colour, thickly blotched and spotted on the upper part with umber-brown, and underlying clouded markings of lilac-grey," providing measurements for two eggs. This description was repeated by Wetmore (1972), while Robinson et al. (2000) described them as "open cups". Wetmore (1972) gave measurements for four eggs in the British Museum collection, two of which (based on collection date) appear to be those measured by Belcher and Smooker (1936), although Wetmore's measurements do not concur with those previously given. Ffrench (1991) doubted the validity of these records and suggested that they referred to nests of red-crowned ant-tanager (Habia rubica). Although Ffrench (1991) mentioned two nests found by Snow and described eggs of $M$. longipes as having a "creamy" ground color and "streaked with purplish brown," he failed to provide an alternative nest description. Subsequent authors have also doubted the Belcher and Smooker (1936) description, suggesting that their placement at more than $1 \mathrm{~m}$ above the ground rules out their belonging to a Myrmeciza. Although it is clear that a modern, well-documented nest description is needed, neither Zimmer and Isler (2003) nor ourselves are convinced that Belcher and Smooker's (1936) original description was incorrect. Their description of the eggs, both in coloration and size, is consistent with those of other Myrmeciza (and other Thamnophilidae). In addition, the original hand-written (Belcher) label for at least one nest of longipes gives a nest height closer to $1.2 \mathrm{~m}$, rather than the published figure of $>2 \mathrm{~m}$ (Douglas G. D. Russel, pers. comm.), a height which would be more consistent with related species (see "Discussion"). 
Chestnut-backed antbird (M. exsul)

Carriker (1910) described the nest and eggs of M. exsul from Costa Rica (sspp. occidentalis and exsul), describing two nests and providing measurements for four eggs. Gross (1926) described a nest with two eggs from Panama (ssp. exsul). Eisenmann (1952) describes nests and eggs from Panama. Skutch (ssp. occidentalis; 1969) described four nests and provided descriptions and measurements for four eggs. Willis and Oniki (ssp. exsul; 1972) described 12 nests and provided measurements for four eggs. Wetmore (ssp. exsul; 1972) described a nest "fastened rather insecurely to the upright stems of vines and bushes, hidden by overhanging leaves ... $40 \mathrm{~cm}$ above the ground ... built of leaves, leaf fibers, and slender vines, with leaves placed vertically over the sides and bottom of the open cup as support for the lining of long, slender fibers."

Based on our examination of the above references and additional personal experience with nests of this species in Ecuador and Costa Rica, M. exsul builds a loosely bound cup of dead vegetative matter supported from below and most frequently set amongst multiple small upright stems or atop many small crisscrossing vines or stems. Most nests have a sparse to well-formed inner lining of dark, flexible fibers.

\section{Ferruginous-backed antbird (M. ferruginea)}

Haverschmidt (ssp. ferruginea; 1962) described and figured a nest and provided measurements for two eggs from Surinam (repeated in Haverschmidt 1968). Stratford (2000) described and figured a nest and two eggs from Brazil.

Both published descriptions of the nests of M. ferruginea are of open, leafy cups placed on the ground, and the figures clearly illustrate that nests are bottom-supported and loosely bound together and have an inner lining of flexible fibers.

\section{Scalloped antbird (M. ruficauda)}

Buzzetti and Barnett (2003) provided excellent descriptions and illustrations of three nests of M. ruficauda soror from Brazil, as well as descriptions and measurements of two eggs. The data from this paper were also presented by Zimmer and Isler (2003). This species clearly builds a bulky open cup of dead vegetative material, supported from the bottom, and placed on or near the ground.

White-bibbed antbird (M. loricata)

The nest and eggs of this species were first described by Euler (1900), who described a single nest and gave descriptions and measurements for two eggs. Nothing further was reported until Buzzetti and Barnett (2003) provided an excellent description, with figures, of the nest and eggs of M. loricata (also given by Zimmer and Isler 2003). What is apparently this same nest was also figured in Buzzetti and Silva (2008). From these descriptions and figures, it is clear that $M$. loricata builds and open, leafy cup, supported from the bottom, and placed on or near the ground.

\section{Squamate antbird (Myrmeciza squamosa)}

The first descriptions, with measurements, of the eggs of M. squamosa were given by von Ihering (1900). The only nest description, however, appears to be a partial one given by Höfling et al. (1986), cited by Link and Ramírez (2003) and Zimmer and Isler (2003). Based on these authors' interpretations, the nest appears to be an open cup built low to the ground, and (most likely) supported from below.

\section{Magdalena antbird (M. palliata)}

Until recently, this species was considered a subspecies of M. laemosticta (Chaves et al. 2010). The nest and eggs of M. palliata were first described by Willis (1984; as M. laemosticta, from Colombia). The eggs were described as white, spotted brown at the larger end and the nest was a "thin cup low in a Piper shrub." This cursory description was later re-published by Willis (1988), amending the egg-spot coloration to cinnamon, but with no additional details added.

We interpret Willis's cursory description of a "thincup" as a woven cup of rootlets. Furthermore, we feel the nest is almost certainly rim-suspended, given the openbranched form of most Piper species, which would provide little opportunity to support a nest from below. A formal, detailed description of the nest of $M$. palliata is still needed.

\section{Esmeraldas antbird (M. nigricauda)}

There is no published nest description for M. nigricauda. The eggs are described from a single Ecuadorian clutch (Schönwetter 1967) as "heavily pigmented with a rosy white ground color and reddish brown to dark purple lines and spots in varying amount" (translation by Wetmore 1972). Although the validity of this record is questioned (Wetmore 1972), such a description is consistent with other Myrmeciza. We point out, however, that it is also similar to descriptions of eggs for most Thamnophilidae (Zimmer and Isler 2003).

Chestnut-tailed antbird (M. hemimelaena)

The only information on the nest and eggs of this species are from two nests described as open cups built slightly 
above the ground, composed of dead leaves (Hennessey 2002). The four eggs contained in these nests were described, but no measurements given. The nests were supported from below by a Geonoma sp. palm, and at least partially attached by the rim (see "Discussion").

\section{Black-throated antbird (M. atrothorax)}

The first nest description for this species appears to be the "previously unpublished" description of a single nest in French Guiana (ssp. atrothorax; by T. Deville and O. Tostain; pers. comm. in Zimmer and Isler 2003). The nest is described as "a cup placed into a clump of sedge, and lined with Marasmius fibers [] c. $20 \mathrm{~cm}$ over water." Schönwetter (1979) provided measurements of two eggs from Bolivia.

Although the details of nest attachment are not provided in the above description, it seems clear that M. atrothorax does not build an enclosed nest. Furthermore, the placement of this nest in a "clump of sedge" suggests that it was a bottom-supported cup.

\section{White-shouldered antbird (M. melanoceps)}

Link and Ramírez (2003) provided the first nest and egg description for this species based on one nest and two eggs observed in Colombia, descriptions later repeated by Zimmer and Isler (2003). Subsequently, Greeney et al. (2004) described a single nest with two eggs from Ecuador. Both studies provided egg measurements and described nests as domed and supported by the leaf rachises of palms, located $<1 \mathrm{~m}$ above the ground.

\section{Goeldi's antbird (M. goeldii)}

Parker (1982) described a nest of this species found on the ground from Peru as a "cup of dried leaves and twigs measur(ing) $18 \mathrm{~cm}$ in diameter." He described a single egg but provided no further details. Zimmer and Isler (2003) expand upon this description slightly, but provided few additional details other than reporting a nest "near the ground." The only detailed description comes from another nest built on the ground in Peru (Lebbin et al. 2007), described and figured as being built into a mound of leaf litter and being similar to the two nests of $M$. fortis described by Wilkinson and Smith (1997). Lebbin et al. (2007) provided a photograph, description, and measurements for one egg.

The first brief description of a nest of M. goeldii, which implies and open cup nest, is likely inaccurate due to the cursory nature of Parker's (1982) examination. It seems likely that nests of this species are indeed loosely formed enclosed nests of leaf litter, as figured by Lebbin et al. (2007).
Plumbeous antbird (M. hyperythra)

Londoño (2003) provided the only description of the nest and eggs of Plumbeous Antbird from eastern Peru. The two nests described and figured are pendant, rim-suspended cups, tightly woven of dark fibers and decorated externally with dead leaves. Londoño (2003) also described and provided measurements for four eggs. This description is repeated in Zimmer and Isler (2003), who also describe a similar nest (still under construction) from Brazil.

\section{Sooty antbird (M. fortis)}

Apparently the only descriptions of the nest and eggs for this species are those of Wilkinson and Smith (1997) from Peru (ssp. fortis), who described two nests built on the ground into mounds of leaf-litter, both with short tunnels leading to spherical chambers neatly lined with interwoven plant fibers. They also described four eggs, but did not provide measurements.

\section{Dull-mantled antbird (M. laemosticta)}

With the recent elevation of $M$. palliata to species status (Chaves et al. 2010), the range of M. laemosticta is confined to Central America (Costa Rica and Panama), and no data have been published on its breeding biology. Here we describe the nest and eggs of M. laemosticta for the first time, based on three nests found in Costa Rica.

On 20 April 2001, J.E.S. and E.C. found a nest with two eggs at Selva, Cartago Province $\left(9^{\circ} 47^{\prime} \mathrm{N}, 83^{\circ} 44^{\prime} \mathrm{W}\right.$; $1050 \mathrm{~m})$. Habitat in the area is a mosaic of humid, primary and second-growth forest. The nest and eggs were collected and deposited in the Museo Nacional de Costa Rica, San José (Catalog \# 388). The nest was situated $2.5 \mathrm{~m}$ from a small creek, $35 \mathrm{~cm}$ above the ground in a small shrub (Melastomataceae) growing at the base of a small cliff. The nest (Fig. 1) was built of tightly woven flexible fibers, with those externally being lighter in color than the darker fibers of the poorly defined lining. Externally the nest was lightly decorated with moss, although most may have been brought incidentally with the structural fibers, measuring $125 \times 180 \mathrm{~mm}$ at the widest points. It was attached by the sides to several thin vines and branches, with no support below. Internally the cup was almost circular, measuring $73 \times 80 \mathrm{~mm}$ in diameter (measured at perpendicular angles), and $49 \mathrm{~mm}$ deep. The walls of the nest varied from 2.5 to $3.0 \mathrm{~cm}$ thick. The two eggs were undeveloped with a pinkish ground color and cinnamon and lavender spots, scrawls and flecks, fairly evenly distributed. They measured $24.4 \times 16.4$ and $24.8 \times 16.35 \mathrm{~mm}$ and both weighed $3.5 \mathrm{~g}$ (Fig. 2). 


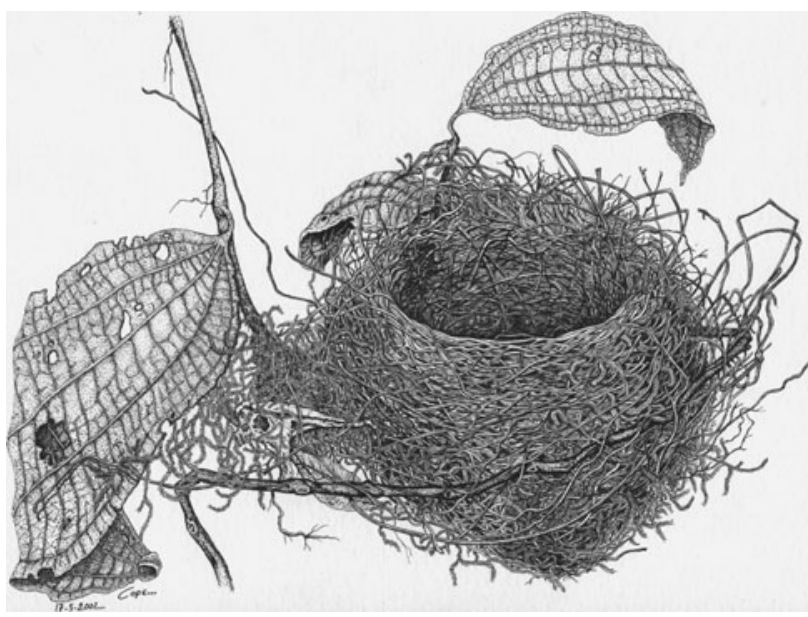

Fig. 1 Drawing of a nest of the Dull-mantled Antbird (Museo Nacional de Costa Rica, San José, Catalog \# 388) collected 20 April 2001, Selva, Cartago Prov., Costa Rica

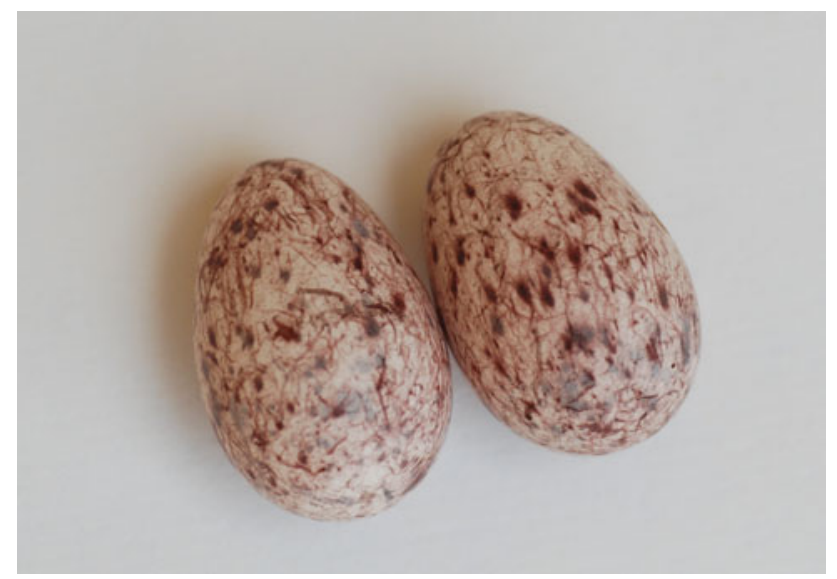

Fig. 2 Complete clutch of the Dull-mantled Antbird (Museo Nacional de Costa Rica, San José, Catalog \# 388) collected 20 April 2001, Selva, Cartago Prov., Costa Rica

On 21 May 2011, H.F.G. found another nest (Fig. 3) with two eggs at San Cristobal, Area de Conservación Guanacaste $\left(10^{\circ} 87^{\prime} \mathrm{N}, 85^{\circ} 39^{\prime} \mathrm{W} ; 640 \mathrm{~m}\right)$. Habitat surrounding the nest was humid, mature second growth forest. The nest was $3 \mathrm{~m}$ from a small stream, placed $50 \mathrm{~cm}$ above the ground in a $1 \mathrm{~m}$ tall sapling. Nest materials were as described for the first nest, again with thicker, redder fibers externally, with finer black fibers internally. Many fibers, especially in the outer portion, were very long $(30-50 \mathrm{~cm})$ and were twisted and wrapped around two vertical and several horizontal branches of the sapling, suspending the cup between them by $6-7 \mathrm{~cm}$ "wings." On one side of the nest, many of the longer fibers were twisted and wrapped into an indistinct ball, nearly the same size as the nest itself. This extra material served to break up the outline of the nest, giving it the overall appearance of disorganized detritus collected naturally. Internally the cup was slightly

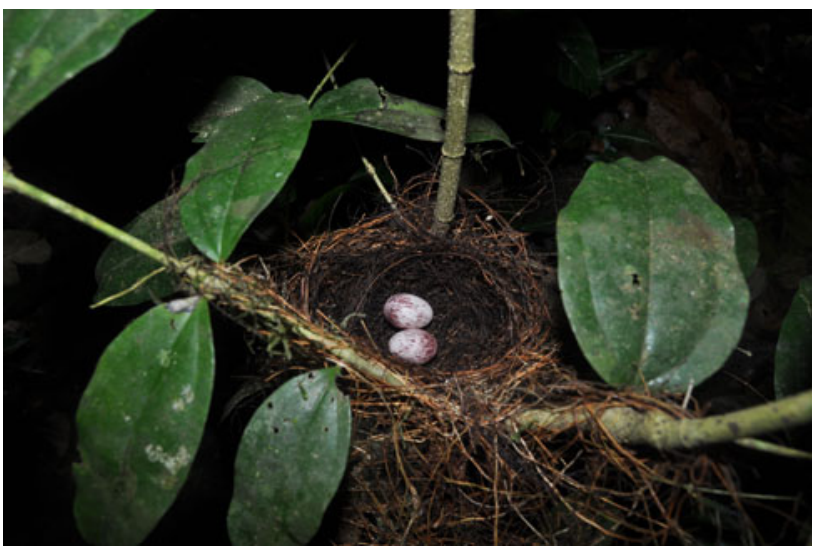

Fig. 3 Nest and complete clutch of the Dull-mantled Antbird photographed 21 May 2011 at San Cristobal, Area de Conservación Guanacaste, Guanacaste Prov., Costa Rica

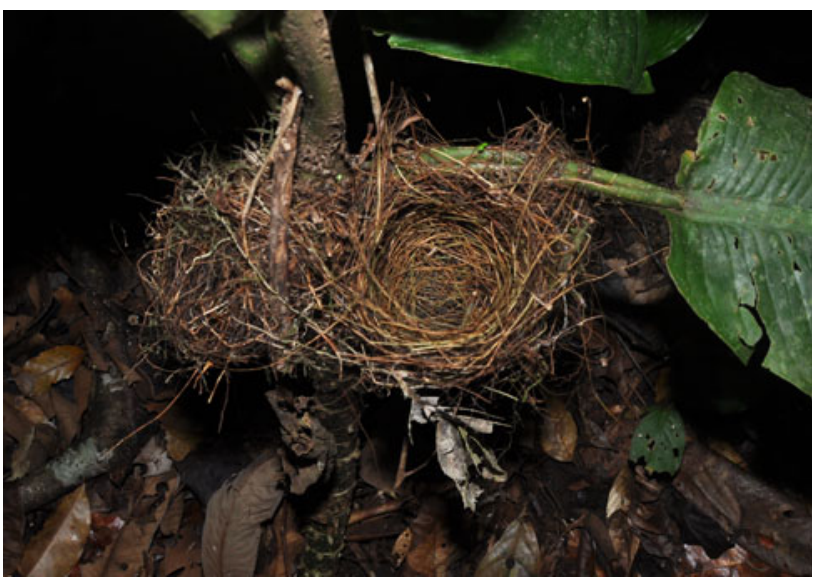

Fig. 4 Nearly completed nest of the Dull-mantled Antbird photographed 21 May 2011 at San Cristobal, Area de Conservación Guanacaste, Guanacaste Prov., Costa Rica

oblong, $8 \times 7 \mathrm{~cm}$ in diameter, and $5 \mathrm{~cm}$ deep (measured at the low point between the supporting wings). Externally, excluding the attachment points, the nest was $7.0 \mathrm{~cm}$ tall and $8.5 \mathrm{~cm}$ in diameter. The walls of the nest were $1.5-2.0 \mathrm{~cm}$ thick and tightly woven, allowing little light to pass through. Both eggs were very slightly developed ( $<1 \mathrm{~mm}$ embryos). The eggs (Fig. 3) were white with heavy cinnamon streaking, flecking, and scrawls combined with a few lavender blotches, all markings concentrated at the larger end. They measured $23.5 \times 16.7$ and $24.0 \times 16.8 \mathrm{~mm}$, and weighed 3.5 and $3.6 \mathrm{~g}$, respectively. We think that the eggs collected in 2001 were likely described as having a pinkish ground color only because they were still very fresh and not fully calcified.

On the same date, H.F.G. found a third nest (Fig. 4), nearly completely built and lacking only the lining of dark fibers. It was $2 \mathrm{~m}$ from a small stream and built $30 \mathrm{~cm}$ up 
Table 1 Architectural categories of Myrmeciza nests

\begin{tabular}{|c|c|c|c|}
\hline Species & $\begin{array}{l}\text { Bottom-supported } \\
\text { cup }\end{array}$ & $\begin{array}{l}\text { Rim-supported } \\
\text { cup }\end{array}$ & Dome \\
\hline M. longipes & $\mathrm{X}$ & & \\
\hline M. exsul & $X$ & & \\
\hline M. ferruginea & $X$ & & \\
\hline M. ruficauda & $X$ & & \\
\hline M. loricata & $X$ & & \\
\hline M. squamosa & $X$ & & \\
\hline M. palliata & & $X$ & \\
\hline M. laemosticta & & $X$ & \\
\hline $\begin{array}{l}\text { M. } \\
\text { hemimelaena }\end{array}$ & $X$ & & \\
\hline M. atrothorax & $X$ & & \\
\hline M. melanoceps & & & $X$ \\
\hline M. goeldii & & & $X$ \\
\hline M. hyperythra & & $X$ & \\
\hline M. fortis & & & $X$ \\
\hline
\end{tabular}

Species are listed in taxonomic order following Remsen et al. (2013). Data sources are given under individual species accounts

saddled between two horizontal leaf petioles of a $50 \mathrm{~cm}$ tall Dieffenbachia plant (Araceae). The nest was well-formed and compositionally and architecturally nearly identical to the previous nest, including the large accumulation of extra material to one side.

\section{Discussion}

All described eggs of Myrmeciza are white with varying amounts of cinnamon and lavender markings. As few eggs have been illustrated in color to allow detailed comparisons, and this description generally applies to most thamnophilid eggs (Zimmer and Isler 2003), we do not discuss eggs any further.

The nests of 14 of the 22 putative Myrmeciza species have now been described, allowing us to make a few preliminary conclusions. Based on nest composition, architecture, and placement, the described nests can be divided into three clear groups (Table 1): (a) bottom-supported open cups built of coarse vegetative matter, (b) rim-suspended open cups woven of thin flexible materials, and (c) domed nests build on or near the ground and composed of coarse vegetative matter. Below, we discuss each of these architectures and the possible phylogenetic significance of emerging patterns within the genus.

(a) The most commonly described nest-type within Myrmeciza is a bulky, thick-walled, open cup composed of various types of course, dead vegetative matter such as leaves, fibers, and sticks. Placement of these nests, with the possible exception of $M$. longipes (see species account), is under $1 \mathrm{~m}$ above the ground, resting upon a generally firm base of crossed branch tangles or at the base of a palm or other plant with similar architecture where multiple leaves arise from a common base. Six other species whose nest architecture falls within this grouping appear to have very similar nests based on published descriptions and our examination of photographs; ferruginea, ruficauda, loricata, squamosa, exsul, and atrothorax. Indeed, the first four of these form a monophyletic group (Bravo 2012), and the available evidence of nest architecture strongly supports this hypothesis. The nest of M. atrothorax is known only from a cursory description of one nest in Zimmer and Isler (2003) but appears to generally fit within this nest-group. It appears, however, to share an affinity for thin-bladed leaves (i.e., sedges, grasses, rather than dicots) with the Stripe-backed Antbird (Myrmorchilus strigilatus; Caziani and Protomastro 1991), to which molecular data suggest atrothorax is closely related (Bravo 2012; Brumfield et al. 2007; Gómez et al. 2010; Moyle et al. 2009). Although the nest architecture of exsul is clearly most similar to that of the above-mentioned ferruginea clade, genetic evidence places it as basal to species building rim-suspended nests (see below for a discussion of this). The final species that builds a bottom-supported open cup is M. hemimelaena, for which Hennessey (2002) provided the only nest description. Although the figures and general description suggest inclusion within this nest group, a clearly stated difference suggests that the architecture of hemimelaena nests may be distinct: they are attached to the substrate by one side. Indeed, although the only description of the nest of hemimelaena (Hennessey 2002) does not appear similar to nest descriptions of Cercomacra, all of which build pouchshaped nests attached to the substrate from one side (Zimmer and Isler 2003), genetic data support a close relationship with this genus (Bravo 2012; Gómez et al. 2010). Given this relationship, it seems likely that castanea (sister species to hemimelaena) builds a bulky, open cup supported from below but partially attached at the rim, with this one-sided rim attachment being the synapomorphy which unites the castanea-hemimelaena-Cercomacra clade (Bravo 2012).

(b) Three species of Myrmeciza are now known to build open cups completely suspended by the rim on at least two sides; palliata, laemosticta, and hyperythra. Molecular data show hyperythra to be imbedded within Schistocichla and unrelated to other Myrmeciza (Bravo 2012; Brumfield et al. 2007). Nest architecture is poorly known within Schistocichla, but the Spot-winged Antbird (Schistocichla leucostigma) builds a rim-suspended cup of thin fibers (ssp. leucostigma; H.F.G. unpublished data) that is quite similar to those of all three of the above Myrmeciza. Interestingly, Bravo (2012) found laemosticta, palliata, nigricauda, berlepschi, and griseiceps to form a clade sister to exsul, 
which clearly builds the "type (a)" nest described above. It is unfortunate that we lack descriptions for the nests of nigricauda, berlepschi, and griseiceps, which may prove to show architectural innovations allowing the evolution from bottom-supported to rim-suspended cups, an architecture that is widespread within the Thamnophilidae (Zimmer and Isler 2003) and has undoubtedly evolved more than once.

(c) The final nest type described within Myrmeciza is distinct from the others by being enclosed or domed. All three species known to build domed nests (melanoceps, goeldii, fortis) are related (Bravo 2012; Brumfield et al. 2007). The two other members of this group, M. zeledoni and $M$. immaculata, do not have described nests, but the clear prediction is that these species will also build domed nests. Indeed, nests of other genera which are closely related to this clade (Gymnocichla, Percnostola, Pyriglena; Bravo 2012) also build domed nests (e.g., Bradley 2008; Protomastro 2002; Willis 1982).

In conclusion, the nest architecture within the polyphyletic Myrmeciza is largely in concordance with emerging phylogenetic hypotheses. The only possible exception is the bulky, bottom-supported cup nest of M. exsul, a species which is apparently most closely allied to a group which builds rim-suspended nests. Detailed nest descriptions for the remaining members of this clade, however, may explain this apparent inconsistency. For the remaining eight species of Myrmeciza with undescribed nests, we hypothesize that: (1) castanea builds predominantly base-supported nests which are partially attached at the rim similar to hemimelaena or possibly pouch-like nests similar to members of Cercomacra, (2) nigricauda, berlepschi, and griseiceps build open cup nests which are partially or entirely supported by the rim, (3) pelzelni and disjuncta build open cup nests, entirely supported from below and possibly including ribbon-like materials (e.g., grass, leaf strips), although the lack of commonality between loud songs, tail and wing movements, and morphometrics among atrothorax, pelzelni, disjuncta and Myrmochilus (Bravo, pers. comm.) may also be mirrored in nest architecture variation, (4) zeledoni and immaculata build domed nests.

Based on the data presented and reviewed here, it is clear that nest architecture provides phylogenetically informative characters, which support the current hypothesized relationships of Myrmeciza antbirds, emphasizing the importance of detailed life-history information for this and other poorly studied groups. Future studies on the nest architecture of these species should pay particular attention to the degree and manner in which nests may be attached, supported, or suspended by their rims. We hope this contribution helps to elucidate important gaps in our knowledge and encourages others to publish information on the nests of these and other poorly known Neotropical birds.
Acknowledgments H.F.G. thanks M. Kaplan, J. Moore, the Population Biology Foundation, and Field Guides Inc. for financial support and D. Janzen and W. Hallawachs for their hospitality in Costa Rica. We thank J. Pérez "Cope" for the nest drawing of M. laemosticta. A. Cuervo, G. Bravo, J. Fjeldså, M. Isler, J. V. Remsen, and Douglas G.D. Russel provided valuable improvements to earlier drafts. We are especially grateful for the contributions of advice and unpublished data made by G. Bravo and M. Isler. For allowing us access to their collections we would like to thank Departamento de Historia Natural, Museo Nacional de Costa Rica, and Museo de Zoología, Universidad de Costa Rica.

Open Access This article is distributed under the terms of the Creative Commons Attribution License which permits any use, distribution, and reproduction in any medium, provided the original author(s) and the source are credited.

\section{References}

Belcher C, Smooker GD (1936) Birds of the colony of Trinidad and Tobago. Part IV. IBIS 6:792-813

Bradley DW (2008) Description of the nest and parental behavior of the bare-crowned antbird (Gymnocichla nudiceps). Ornitol Neotrop 19:153-156

Bravo GA (2012) Phenotypic and niche evolution in the antbirds (Aves, Thamnophilidae). Ph.D Dissertation, Louisiana State University, Baton Rouge

Brumfield RT, Tello JG, Cheviron ZA, Carling MD, Crochet N (2007) Phylogenetic conservatism and antiquity of a tropical specialization: army-ant-following in the typical antbirds (Thamnophilidae). Mol Phylogen Evol 45:1-13

Buzzetti DRC, Barnett JM (2003) Description of the nest and eggs of two Myrmeciza antbirds endemic to the Atlantic forest of Brazil. Cotinga 20:89-93

Buzzetti DRC, Silva S (2008) Berços da vida, ninhos de aves brasileiras. Editora Terceiro Nome, São Paulo

Carriker MA Jr (1910) An annotated list of the birds of Costa Rica, including Cocos Island. Ann Carnegie Mus 6:314-915

Caziani SM, Protomastro JJ (1991) Nest and eggs of the stripedbacked Antbird (Myrmorchilus strigilatus). Condor 93:445-446

Chaves JC, Cuervo AM, Miller MJ, Cadena CD (2010) Revising species limits in a group of Myrmeciza antbirds reveals a cryptic species within $M$. laemosticta (Thamnophilidae). Condor 112:718-730

Donegan TM (2012) Geographical variation in immaculate antbird Myrmeciza immaculata, with a new subspecies from the Central Andes of Colombia. Bull BOC 132: 3-40

Eisenmann E (1952) Annotated list of the birds of Barro Colorado Island, Panama Canal Zone. Smithonian Misc Coll 62, Washington, DC

Euler C (1900) Descrição de ninhos e ovos das aves do Brazil. Rev Mus Paulista 4:9-148

ffrench R (1991) Birds of Trinidad and Tobago. Cornell University Press, Ithaca

Gómez JP, Bravo GA, Brumfield RT, Tello JG, Cadena CD (2010) A phylogenetic approach to disentangling the role of competition and habitat filtering in community assembly of Neotropical forest birds. J Anim Ecol 79:1181-1192

Greeney HF, Port J (2010) Nest architecture of the Brown Nunlet (Nonnula brunnea) and observations on the nesting of other Ecuadorian puffbirds. Ornithol Col 9:31-37

Greeney HF, Gelis RA, White R (2004) Notes on breeding birds from an Ecuadorian lowland forest. Bull BOC 124:28-37 
Gross AO (1926) Barro Colorado Island biological station. Ann Rep Board Regents Smithsonian Inst 1925-1926:327-342

Haverschmidt F (1962) Notes on some Surinam breeding birds (II). Ardea 50:173-179

Haverschmidt F (1968) Birds of Surinam. Oliver \& Boyd, London

Hennessey AB (2002) First description of the nest of the Chestnuttailed antbird. Wilson Bull 114:161-164

Höfling E, Almeida-Camargo HF, Imperatriz-Fonesca L (1986) Aves na Mantiqueira. ICI Brazil S.A, São Paulo

Irestedt M, Fjeldså J, Nylander JAA, Ericsson PG (2004) Phylogenetic relationships of typical antbirds (Thamnophilidae) and test of incongruence based on Bayes factors. BMC Evol Biol 4:23

Lebbin DJ, Hosner PA, Andersen MJ, Valdez U, Tori WP (2007) First description of the nest and eggs of the white-lined antbird (Percnostola lophotes), and breeding observations of poorly known birds inhabiting Guadua bamboo in southeastern Peru. Bol Soc Antioqueña Ornit 17:119-132

Link A, Ramírez B (2003) First description of the nest, eggs and nestlings of the white-shouldered antbird (Myrmeciza melanoceps). Ornithol Neotrop 14:423-429

Londoño GA (2003) First description of the nest and eggs of the Plumbeous (Myrmeciza hyperythra) and the black-faced (Myrmoborus myotherinus) antbirds. Ornithol Neotrop 14:405-410

Miller ET, Greeney HF (2008) Clarifying the nest architecture of the Silvicultrix clade of Ochthoeca chat-tyrants (Tyrannidae). Ornithol Neotrop 19:361-370

Moyle RG, Chesser RT, Brumfield RT, Tello JG, Marchese DJ, Cracraft J (2009) Phylogeny and phylogenetic classification of the antbirds, ovenbirds, woodcreepers, and allies (Aves: passeriformes: infraorder Furnariides). Cladistics 25:386-405

Parker TA III (1982) Observations of some unusual rain-forest and marsh birds in southeastern Peru. Wilson Bull 94:477-493

Protomastro JJ (2002) Notes on the nesting of white-shouldered fireeye Pyriglena leucoptera. Cotinga 17:73-75

Remsen JV, Jr, Cadena CD, Jaramillo A, Nores M, Pacheco JF, PérezEmán J, Robbins MB, Stiles FG, Stotz DF, Zimmer KJ (2013) A classification of the bird species of South America. http://www.museum.lsu.edu/ Remsen/SACCBaseline.html. Accessed 18 Feb 2013

Restrepo SD, Londoño GA (2011) Análisis filogenético de la arquitectura de nidos y comportamientos reproductivos de los hormigueros neotropicales (Aves: Thamnophilidae) In: More A,
Olaechea DG, Olaechea AG (eds) Libro de Resúmenes IX Congreso de Ornitología Neotropical (versión preliminar), Cuzco, Peru, pp 167-168

Ridgely R, Tudor G (1994) The birds of South America, vol 2, The suboscine passerines. Univ Texas Press, Austin

Robinson WD, Robinson TR, Robinson SK, Brawn JD (2000) Nesting success of understory forest birds in central Panama. J Avian Biol 31:151-164

Schönwetter M (1967) Handbuch der Oölogie. Akademie, Germany

Schönwetter M (1979) Handbuch der Oölogie vol 2. Akademie, Berlin, Germany

Sheldon FH, Winkler DW (1999) Nest architecture and avian systematic. Auk 116:875-877

Skutch AF (1969) Life histories of Central American birds III. Pacific Coast Avifauna no. 35, Berkeley, CA

Stratford JA (2000) A ferruginous-backed antbird, Myrmeciza ferruginea, nest from central Amazonas, Brazil. Ararajuba $8: 43-44$

von Ihering H (1900) Catálogo crítico-comparativo dos ninhos e ovos das aves do Brazil. Rev Mus Paulista 4:191-300

Wetmore A (1972) The birds of the Republic of Panama. Part 3. Passeriformes: Dendrocolaptidae (woodcreepers) to Oxyruncidae (sharpbills). Smithsonian Institution Press, Washington

Wilkinson FA, Smith UR (1997) The first nest records of the sooty antbird (Myrmeciza fortis) with notes on eggs and nestling development. Wilson Bull 109:319-324

Willis EO (1982) The behavior of Black-headed Antbirds (Percnostola rufifrons) (Formicariidae). Rev Bras Biol 42:233-247

Willis EO (1984) Hylophylax, Hypocnemoides, and Myrmoderus (Aves, Formicariidae) as army ant followers. Rev Bras Zool 2:159-164

Willis EO (1988) Behavioral notes, breeding records, and range extensions for Colombian birds. Rev Acad Col Cien Exactas Fís Nat 16:137-150

Willis EO, Oniki Y (1972) Ecology and nesting behavior of the chestnut-backed antbird (Myrmeciza exsul). Condor 74:87-98

Zimmer KJ, Isler ML (2003) Thamnophilidae (Antbirds). In: del Hoyo J, Elliott A, Christie D (eds) Handbook of the birds of the world, vol 8., Lynx EdicionsBarcelona, Spain, pp 448-681

Zyskowski K, Prum RO (1999) Phylogenetic analysis of the nest architecture of Neotropical ovenbirds (Furnariidae). Auk 116:891-911 